\title{
ANALISIS PROFIL KONSUMEN UNTUK PEMBUATAN APLIKASI INDEKOS DENGAN PENDEKATAN DESAIN PROPOSISI NILAI
}

\author{
Nugroho Wisnu Murti ${ }^{1}$ \\ Kristina Sisilia ${ }^{2}$ \\ ${ }^{1}$ Administrasi Bisnis, Fakultas Komunikasi dan Bisnis, Universitas Telkom \\ 1nugrohowisnu46@gmail.com \\ ${ }^{2}$ Administrasi Bisnis, Fakultas Komunikasi dan Bisnis, Universitas Telkom \\ ${ }^{2}$ kristina@telkomuniversity.ac.id
}

\begin{abstract}
They are seeing the development of internet users in Indonesia which is growing rapidly. This is the basis for the emergence of applications that can facilitate the community in doing their work. One of them is doing work in terms of finding a homestay, especially in the student segment. The phenomenon found, the information offered is incomplete and the absence of services to help move goods. This study aims to determine the consumer profile which includes perceptions and expectations for the homestay application customer segment, namely students, so that it can be a reference for creating value propositions that are relevant for homestay applications. The study uses a qualitative approach that is descriptive. Data collection techniques used include interviews, observation, and documentation. In this study, the design of a consumer profile consists of three parts, namely customer jobs, customer science, and customer gains in the Value Proposition Design taken from Alexander Osterwalder and Yves Pigneur. In this study, generated perceptions and expectations of consumers of boarding room applications, among others, requires complete information, a lot of boarding references, there are features of ratting, booking, and chat forums, as well as there are goods transport services.
\end{abstract}

Keywords: Value Proposition Design, Consumer Profile.

PENDAHULUAN

Perkembangan internet di Indonesia saat ini terjadi begitu cepat dan dinamis. Menurut APJII (Asosiasi Penyelenggara Jasa Internet Indonesia) dalam Infografis Penetrasi dan Perilaku Pengguna Internet Indonesia 2017 (2018:11) bahwa pengguna internet di Indonesia pada tahun 2017 mencapai lebih dari 143 juta orang dengan presentase pengguna terbanyak usia 1934 tahun atau yang biasa disebut generasi milenial dengan 49,52 persen.
Internet menjadi fenomena di masyarakat karena dapat mengatasi berbagai masalah dengan memberikan seluruh informasi dan apa yang masyarakat butuhkan, sekaligus memberikan kemudahan akses bagi penggunanya, sehingga masyarakat dapat menyelesaikan pekerjaan mereka dengan mudah. Saat ini internet telah mengubah kebiasaan masyarakat dari melakukan hal yang bersifat manual menjadi otomatis dan praktis. Hal tersebut menjadikan kegiatan 
masyarakat menjadi efektif dan efisien.

Terbukti dalam semua hal yang dibutuhkan masyarakat dapat dipenuhi hanya dengan menggunakan telepon genggam atau laptop dengan koneksi internet saja, yaitu dengan membuka web atau aplikasi, lalu memilih apa yang mereka butuhkan, selanjutnya klik sesuai dengan apa yang mereka butuhkan, kemudian melakukan pembayaran, maka akan ada pemberitahuan dan apa yang masyarakat butuhkan tersebut akan sampai pada tujuan ataupun akan langsung terpenuhi saat itu juga, contohnya untuk membeli tiket kereta api, masyarakat tidak perlu datang ke stasiun dan mengantri, saat ini hanya dengan membuka aplikasi seperti KAI Accees sudah bisa pesan tiket kereta tanpa harus ke stasiun dan mengantri

Berkaitan dengan hal tersebut, penulis melihat peluang berdasarkan apa yang penulis dan teman-teman penulis alami sebagai mahasiswa disalah satu perguruan tinggi swasta di Bandung yaitu Universitas Telkom. Penulis melakukan analisis terhadap masalahmasalah dalam memenuhi kebutuhan pokok sebagai seorang mahasiswa. Pertama adalah sandang yang berarti pakaian untuk digunakan sehari-hari, lalu pangan atau makanan yang merupakan kebutuhan utama seorang manusia, kemudian papan yang merupakan tempat tinggal. Fenomena yang terjadi saat ini dalam memenuhi kebutuhan sandang, pangan, dan papan, mahasiswa telah dimudahkan dengan hadirnya e-businesses dan e-commerce berbasis aplikasi seperti Gojek membantu mahasiswa dalam memenuhi kebutuhan pangan dan transportasi lewat layanan GoRide dan GoFood, Zalora membantu mahasiswa dalam memenuhi kebutuhan sandang, Mamikos membantu mahasiswa dalam memebuhi kebutuhan papan dengan membantu mencarikan indekos, dan lain sebagainya.

Dalam praktiknya di lapangan, mahasiswa hanya dimudahkan pada kebutuhan pangan dengan adanya layanan pengiriman atau delivery baik yang ditawarkan oleh restoran maupun penyedia jasa pengiriman makanan seperti, Go Food, Grab Food, dan Dkantin. Kemudian mahasiswa juga dimudahkan dengan adanya situs belanja online seperti Tokopedia, Shopee, Zalora yang dapat mempermudah pemenuhan kebutuhan sandang. Akan tetapi, mahasiswa masih menemui kesulitan dalam memenuhi kebutuhan papan dalam hal ini adalah mencari tempat tinggal atau indekos, pencarian indekos kebanyakan masih secara manual dengan menyusuri satu per satu setiap daerah di lingkungan kampus untuk mendapatkan informasi kamar 
yang masih tersedia, harga sewa, dan fasilitas indekos. Tidak hanya itu, masalah kembali muncul ketika mahasiswa telah menemukan indekos yang sesuai, yaitu persoalan dalam pemindahan barang-barangnya seperti kasur, lemari, meja, dan sebagainya dari indekos lama atau asrama ke indekos yang akan ditempati. Tentu hal tersebut akan menghabiskan tenaga, waktu, dan biaya.

Saat ini, terdapat berbagai aplikasi indekos Indonesia. Salah satunya adalah aplikasi Mamikos yang menawarkan informasi indekos di seluruh indonesia yang meliputi fasilitas, lokasi, harga, dan jumlah kamar yang masih tersedia. Dalam aplikais Mamikos hanya terdapat 131 indekos, padahal jumlah indekos di sekitaran Universitas Telkom jumlahnya lebih dari itu. Mamikos juga tidak menyediakan layanan untuk membantu pindahan atau menyediakan jasa angkut bagi konsumennya, sehingga terdapat perbedaan antara jumlah indekos yang tersedia di aplikasi Mamikos dengan jumlah indekos yang ada di di lapangan.

$$
\text { Terdapat juga Info }
$$

Kost/Kontrakan yaitu e-businesses yang menawarkan layanan informasi indekos di Universitas Telkom. Saat ini Info Kost/Kontrakan telah menguasai pasar indekos di Universitas Telkom dan dalam kegiatannya menggunakan media sosial Line@ dengan menggunakan sistem paid promote sesuai layanan yang ditawarkan kepada pemilik indekos yang mau mempromosikan indekosnya. Akan tetapi Info Kost/Kontarakan hanya menawarkan layanan informasi indekos saja dan belum memberikan layanan yang tidak kalah penting yaitu, menyedikan layanan jasa angkut barang atau pindahan bagi konsumennya. Saat ini terdapat 13.685 akun line personal yang terhubung dengan Info Kost/Kontrakan dengan melakukan posting rata-rata dua hari sekali.

Selain itu, untuk menguatkan apakah mahasiswa Universitas Telkom merasakan apa yang dirasakan oleh peneliti tentang permasalahan dalam mencari indekos, peneliti melakukan prawawancara kepada tiga mahasiswa untuk meyakinkan apakah masalah yang dirasakan oleh peneliti juga dirasakan oleh mahasiswa lain. Informan tersebut tentu dikhususkan kepada mahasiswa tingkat dua yang antara bulan Mei-Juni kemarin melakukan dan merasakan bagaimana mencari indekos di sekitar Universitas Telkom, sehingga ingatan mereka dalam melakukan dan merasakan pengalaman dalam mencari indekos masih terbayangkan

Hasil yang didapat adalah mahasiswa dalam melakukan pekerjaan untuk mencari indekos masih terbilang cukup sulit karena masih mencari 
informasi indekos dengan bertanyatanya kepada kakak tingkat atau temanteman mereka, masih mencari dengan berkeliling di sekitar universitas telkom, lalu melakukan survei satu demi satu indekos untuk menanyakan ketersedian dan melihat fasilitas kamar. Kemudian mereka merasakan ketidaknyamanan bahwa dalam melakukan pekerjaan mencari indekos, waktu, tenaga, pikiran, dan biaya mereka terkuras begitu banyak. Selain itu, saat sudah mendapatkan indekos mereka kesulitan dalam memindahkan barang-barang mereka dari asrama ke indekos akan mereka huni karena mereka melakukannya secara sendiri atau mandiri.

Peneliti juga mendapatkan informasi terkait nilai yang diberikan oleh aplikasi indekos atau sejenisnya, bahwa aplikasi indekos atau sejenisnya saat ini sudah membantu mereka dalam mencari indekos tetapi referensi indekos yang disediakan masih kurang, informasi tentang fasilitas, harga, lokasi, dan ketersediaan masih kurang. Lalu mereka mengharapkan ada aplikasi yang dapat memudahkan mereka dalam mencari indekos, dapat membantu memindahkan barang-barang mereka ke indekos yang akan mereka huni, memiliki fitur dan layanan yang dapat membantu juga mudah digunakan, dan memiliki desain yang menarik.
Berkaitan permasalahan yang telah diuraikan di atas maka perlu adanya e-businesses berbasis aplikasi indekos di Universitas Telkom yang tidak hanya menyediakan informasi indekos tetapi juga mengatasi berbagai masalah yang berkaitan dengan indekos yang terjadi di lapangan karena pasar indekos di Universitas Telkom merupakan pasar yang besar. Hal ini dibuktikan dengan Universitas Telkom memiliki jumlah mahasiswa lebih dari 20.000 dan lebih dari setengah jumlah mahasiswa tersebut adalah mahasiswa dari luar Kota Bandung yang tentu membutuhkan tempat tinggal atau indekos. Sehingga peneliti menggunakan pendekatan Desain Proposisi Nilai sebagai alat untuk menganalisis profil konsumen karena Desain Proposisi Nilai merupakan pendekatan yang dikembangkan oleh Alexander Osterwalder berserta kawankawannya yang berasal dari Swiss dan pendekatan ini merupakan turunan dari Bisnis Model Kanvas yang bertujuan untuk mendesain produk dan jasa yang sesuai dengan apa yang diinginkan oleh konsumen.

\section{KAJIAN LITERATUR}

Menurut Osterwalder dan Pigneur dalam Business Model Generation (2010:22) Proposisi nilai diartikan sebagai kumpulan produk dan jasa yang memberikan nilai kepada 


\section{FAKULTAS EKONOMI DAN BISNIS UNIVERSITAS WIRARAJA - SUMENEP}

segmen pelanggan yang spesifik.

Proposisi nilai juga menjadi suatu alasan yang membuat pelanggan dapat beralih dari satu perusahaan ke perusahaan lain dan dapat memecahkan masalah atau kepuasan akan kebutuhan pelanggan. Desain Proposisi Nilai adalah tentang menerapkan alat dalam mencari macammacam proposisi nilai yang dinginkan oleh pelanggan kemudian menjaga proposisi nilai tersebut tetap selaras dengan apa yang benar-benar pelanggan inginkan. Desain Proposisi Nilai merupakan penerapan dari value proposition canvas (kanvas proposisi nilai) yang merupakan alat untuk membantu menciptakan value untuk pelanggan

Profil Konsumen

Menurut Osterwalder dan Pigneur dalam Value Propositon Design (2016:9) Profil Konsumen menjelaskan segmen pelanggan tertentu di model bisnis yang lebih terstruktur dan rinci.
Perusahaan harus dapat memahami karakteristik demografi pelanggan dan mengembangkan pemahaman tentang aspirasi, kepedulian, perilaku, dan lingkungan yang lebih baik. Profil Konsumen terdiri dalam tiga jenis yaitu, customer jobs, pains, dan gains.

Customer jobs (Pekerjaan Pelanggan)

$$
\text { Pekerjaan pelanggan }
$$

menggambarkan hal-hal yang pelanggan coba lakukan dalam pekerjaan mereka atau dalam hidup mereka. Pekerjaan pelanggan dapat menjadi tugas yang mereka coba lakukan dan selesaikan, kebutuhan yang mereka coba penuhi, atau masalah yang mereka coba pecahkan. Saat menyelediki pekerjaan pelanggan, perspektif yang kita anggap bahwa itu penting mungkin berbeda dengan hal yang dianggap penting oleh pelanggan dalam pekerjaan yang ingin mereka diselesaikan. Berikut merupakan tabel tentang jenis pekerjaan pelanggan.

Gambar 1

Customer Profile

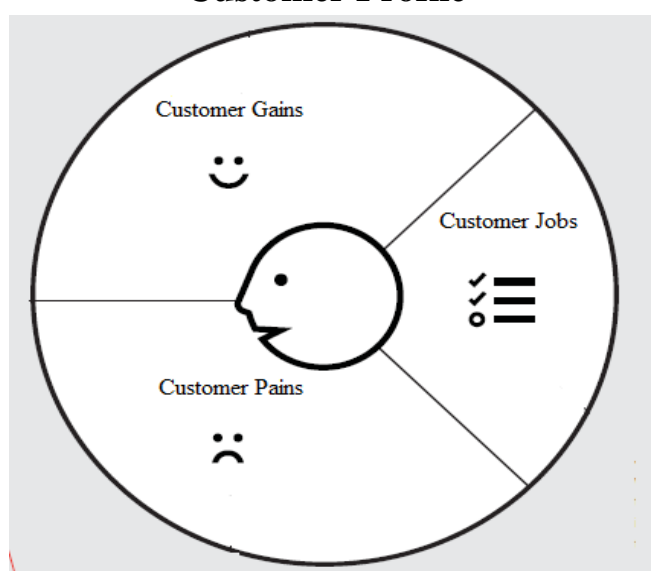

Sumber : Osterwalder, Pigneur, Bernarda, dan Smith (2014: 9) 
Customer jobs (Pekerjaan Pelanggan)

Pekerjaan

pelanggan

menggambarkan hal-hal yang pelanggan coba lakukan dalam pekerjaan mereka atau dalam hidup mereka. Pekerjaan pelanggan dapat menjadi tugas yang mereka coba lakukan dan selesaikan, kebutuhan yang mereka coba penuhi, atau masalah yang mereka coba pecahkan. Saat menyelediki pekerjaan pelanggan, perspektif yang kita anggap bahwa itu penting mungkin berbeda dengan hal yang dianggap penting oleh pelanggan dalam pekerjaan yang ingin mereka diselesaikan. Berikut merupakan tabel tentang jenis pekerjaan pelanggan.

Customer pains (Rasa Sakit Pelanggan)

$\begin{array}{ccr}\text { Rasa } & \text { Sakit } & \text { Pelanggan } \\ \text { menggambarkan } & \text { hal-hal } & \text { yang }\end{array}$
mengganggu pelanggan sebelum, selama, dan setelah mencoba dalam menyelesaikan pekerjaan mereka. Rasa Sakit Pelanggan juga menngambarkan risiko yaitu, potensi hasil buruk atau mendapatkan hasil yang buruk pada pelanggan dalam menyelesaikan pekerjaan mereka. Dalam menentukan Rasa Sakit Pelanggan, harus mengidentifikasi tiga jenis keluhan pelanggan dan seberapa parah pelanggan menemukan rasa sakit itu. Berikut merupakan tabel penjelasan tiga jenis keluhan pelanggan.

Customer gains (Keuntungan atau Pencapaian Pelanggan)

$$
\text { Keuntungan Pelanggan }
$$

menggambarkan manfaat dan hasil yang diinginkan oleh pelanggan. Termasuk keuntungan secara emosional, fungsional, hemat biaya, dan emosi positif. Sebagian pencapaian didapatkan dari apa yang pelanggan butuhkan, apa yang diharapkan pelanggan, dan apa yang tidak terbayangkan oleh pelanggan. Perusahaan harus menjadi nilai positif di mata pelanggan dengan mampu membantu pelanggan untuk mencapai yang yang mereka inginkan. Berikut merupakan tabel penjelasan tiga jenis Keuntungan

Pelanggan.

\section{Gambar 2}

\section{Kerangka Pemikiran}

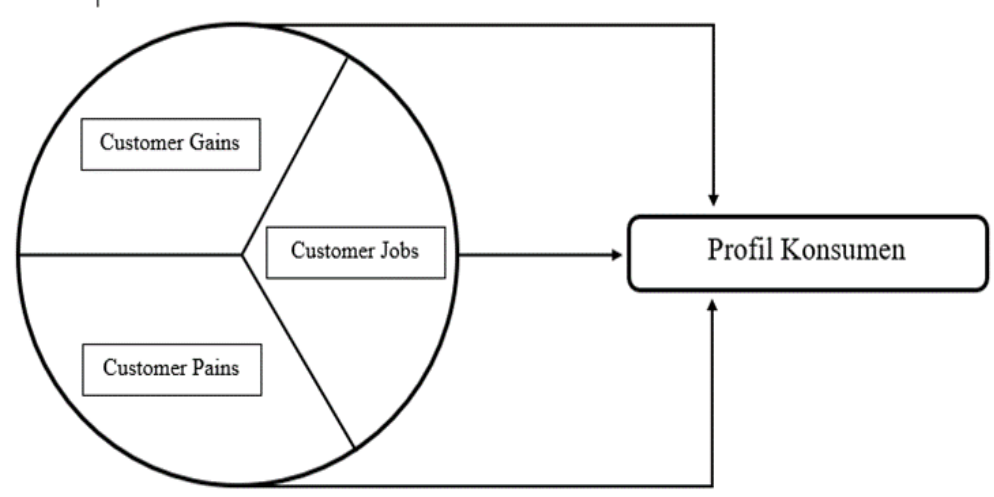

Sumber : Osterwalder dan Pigneur (2014)

PERFORMANCE : Jurnal Bisnis \& Akuntansi Volume 9, No.2,September 2019 


\section{METODOLOGI PENELITIAN}

Penelitian ini menggunakan jenis penelitian desktipsif dengan pendekatan kualitatif. Fokus dalam penelitian ini ditetapkan berdasarkan tujuan penelitian. Teknik pengumpulan data yang digunakan adalah wawancara, observasi, dan dokumentasi. Dalam menentukan profil konsumen dan tahapan penelitian, penelitian ini menggunakan desain kanvas proposisi nilai dari Alexander Osterwalder dan Yves Pigneur. Instrumen pada peneitian ini adalah peneliti sendiri. Teknik untuk menguji keabsahan data menggunakan triangulasi. Lokasi penelitian di daerah Universitas Telkom, Bandung. Lama penelitian ini selama delapan minggu dengan wawancara dilakukan pada minggu pertama sampai dengan minggu keenam, observasi dilakukan diminggu kedua sampai dengan minggu keenam, dan dokumentasi dilakukan pada minggu kelima sampai dengan minggu kedelapan.

\section{HASIL DAN PEMBAHASAN}

Tabel 1

\section{Identitas Informan}

\begin{tabular}{|c|c|c|c|c|c|c|}
\hline No & Nama & $\begin{array}{l}\text { Usia } \\
\text { (Thn) }\end{array}$ & Jurusan & Tingkat & $\begin{array}{c}\text { Aktor } \\
\text { Penelitian }\end{array}$ & Keterangan \\
\hline 1 & $\begin{array}{l}\text { Aditya Galih } \\
\text { Saputro }\end{array}$ & 19 & $\begin{array}{l}\text { Mahasiswa } \\
\text { Fakultas } \\
\text { Industri } \\
\text { Kreatif }\end{array}$ & 2 & $\begin{array}{c}\text { Segmen } \\
\text { Mahasiswa }\end{array}$ & $\begin{array}{l}\text { Mahasiswa semester tiga } \\
\text { yang sebelumnya tinggal di } \\
\text { asrama dan pada tiga bulan } \\
\text { kemarin mencari indekos }\end{array}$ \\
\hline 2 & $\begin{array}{l}\text { Muhammad } \\
\text { Arif } \\
\text { Ronindio } \\
\text { Wardhana }\end{array}$ & 19 & $\begin{array}{l}\text { Mahasiswa } \\
\text { Fakultas } \\
\text { Industri } \\
\text { Kreatif }\end{array}$ & 2 & $\begin{array}{c}\text { Segmen } \\
\text { Mahasiswa }\end{array}$ & $\begin{array}{l}\text { Mahasiswa semester tiga } \\
\text { yang sebelumnya tinggal di } \\
\text { asrama dan pada tiga bulan } \\
\text { kemarin mencari indekos }\end{array}$ \\
\hline 3 & $\begin{array}{l}\text { Chandra } \\
\text { Triswhati }\end{array}$ & 19 & $\begin{array}{l}\text { Mahasiswa } \\
\text { Fakultas } \\
\text { Komunikasi } \\
\text { dan Bisnis }\end{array}$ & 2 & $\begin{array}{c}\text { Segmen } \\
\text { Mahasiswa }\end{array}$ & $\begin{array}{l}\text { Mahasiswa semester tiga } \\
\text { yang sebelumnya tinggal di } \\
\text { asrama dan pada tiga bulan } \\
\text { kemarin mencari indekos }\end{array}$ \\
\hline 4 & $\begin{array}{l}\text { Pradena } \\
\text { Rizal } \\
\text { Mahendra } \\
\text { Ramadhan }\end{array}$ & 19 & $\begin{array}{l}\text { Mahasiswa } \\
\text { Fakultas } \\
\text { Komunikasi } \\
\text { dan Bisnis }\end{array}$ & 2 & $\begin{array}{c}\text { Segmen } \\
\text { Mahasiswa }\end{array}$ & $\begin{array}{l}\text { Mahasiswa semester tiga } \\
\text { yang sebelumnya tinggal di } \\
\text { asrama dan pada tiga bulan } \\
\text { kemarin mencari indekos }\end{array}$ \\
\hline 5 & $\begin{array}{l}\text { Alif } \\
\text { Nugroho }\end{array}$ & 20 & $\begin{array}{l}\text { Mahasiswa } \\
\text { Fakultas } \\
\text { Rekayasa } \\
\text { Industri }\end{array}$ & 3 & $\begin{array}{c}\text { Segmen } \\
\text { Mahasiswa }\end{array}$ & $\begin{array}{l}\text { Mahasiswa semester lima } \\
\text { yang sebelumnya tinggal di } \\
\text { asrama dan pada tiga bulan } \\
\text { kemarin mencari indekos }\end{array}$ \\
\hline 6 & $\begin{array}{l}\text { Muhammad } \\
\text { Alfisar } \\
\text { Rachman }\end{array}$ & 20 & $\begin{array}{l}\text { Mahasiswa } \\
\text { Fakultas } \\
\text { Informatika }\end{array}$ & 3 & $\begin{array}{l}\text { Segmen } \\
\text { Mahasiswa }\end{array}$ & $\begin{array}{l}\text { Mahasiswa semester lima } \\
\text { yang sebelumnya tinggal di } \\
\text { asrama dan pada tiga bulan } \\
\text { kemarin mencari indekos }\end{array}$ \\
\hline
\end{tabular}


FAKULTAS EKONOMI DAN BISNIS UNIVERSITAS WIRARAJA - SUMENEP

\begin{tabular}{|c|c|c|c|c|c|c|}
\hline No & Nama & $\frac{\text { Usia }}{\text { (Thn) }}$ & Jurusan & Tingkat & $\frac{\text { Aktor }}{\text { Penelitian }}$ & Keterangan \\
\hline 7 & $\begin{array}{l}\text { Panji } \\
\text { Bagaskara }\end{array}$ & 20 & $\begin{array}{l}\text { Mahasiswa } \\
\text { Fakultas } \\
\text { Informatika }\end{array}$ & 3 & $\begin{array}{c}\text { Segmen } \\
\text { Mahasiswa }\end{array}$ & $\begin{array}{l}\text { Mahasiswa semester lima } \\
\text { yang sebelumnya tinggal di } \\
\text { asrama dan pada tiga bulan } \\
\text { kemarin mencari indekos }\end{array}$ \\
\hline 8 & $\begin{array}{l}\text { Amrina } \\
\text { Ardyanti }\end{array}$ & 19 & $\begin{array}{l}\text { Mahasiswa } \\
\text { Fakultas } \\
\text { Ekonomi } \\
\text { dan Bisnis }\end{array}$ & 2 & $\begin{array}{c}\text { Segmen } \\
\text { Mahasiswa }\end{array}$ & $\begin{array}{c}\text { Mahasiswa semester tiga } \\
\text { yang pernah mendapatkan } \\
\text { indekos dari Info } \\
\text { Kos/Kontrakan }\end{array}$ \\
\hline 9 & $\begin{array}{l}\text { Ghanes } \\
\text { Nadia Efrata }\end{array}$ & 20 & $\begin{array}{l}\text { Mahasiswa } \\
\text { Fakultas } \\
\text { Ekonomi } \\
\text { dan Bisnis }\end{array}$ & 3 & $\begin{array}{c}\text { Segmen } \\
\text { Mahasiswa }\end{array}$ & $\begin{array}{l}\text { Mahasiswa semester lima } \\
\text { yang yang sebelumnya } \\
\text { tinggal di asrama dan pada } \\
\text { satu tahun kemarin mencari } \\
\text { indekos, pernah } \\
\text { menggunakan jasa } \\
\text { pengangkut barang }\end{array}$ \\
\hline
\end{tabular}

Sumber : Diolah oleh peneliti

Dalam penelitian ini, peneliti menekan tombol enter atau tombol cari melakukan observasi tentang aplikasiaplikasi yang menawarkan informasi indekos dan jasa pengangkut barang. Hal-hal tersebut dilakukan untuk menguatkan atau sebagai bukti dari pernyataan-pernyataan yang telah diutarakan oleh informan. Saat ini aplikasi atau sejenisnya yang menawarkan informasi indekos, antara lain Mamikos, Info Kost/Kontrakan, dan Kost Seeker, akan tetapi peneliti hanya mengamati Mamikos dan Info Kost/Kontrakan saja, karena kedua aplikasi tersebut adalah aplikasi yang sering digunakan oleh mahasiswa dan juga informan pada penelitian ini.

Penggunaan media online dalam mencari informasi merupakan hal yang mudah untuk dilakukan karena mahasiswa tinggal menggunakan smartphone atau laptop dengan koneksi internet. Memasukkan kata kunci seperti nama, lokasi, harga indekos lalu pada smartphone atau laptop. Lalu akan muncul rekomendasi indekos-indekos pada aplikasi atau sejenisnya yang sesuai dengan apa yang mahasiswa tersebut cari. Terlebih dahulu peneliti akan menjelaskan Aplikasi Mamikos. Berikut merupakan gambar dari aplikais indekos Mamikos.

Berdasarkan observasi peneliti pada Mamikos, peneliti berperan sebagai pengguna Mamikos. Peneliti melakukan langkah-langkah yang telah dijelaskan di atas dalam mencari indekos pada aplikasi tersebut. Peneliti mengamati banyak fitur yang ditawarkan pada aplikasi tersebut antara lain (1) fitur pencarian dengan kata kunci dan dengan peta yang terhubung dengan Google Map, (2) fitur filter yang digunakan untuk menyaring informasi berdasarkan tipe, jangka waktu, dan rentang harga indekos, (3) fitur pencarian apartemen, (4) fitur hubungi indekos atau forum 
obrolan antara pemilik indekos dan calon konsumen, (5) fitur review dari orang lain terhadap indekos, (6) fitur verifikasi sebagai bukti bahwa alamat dan nomor telepon telah sesuai, serta (7) fitur pencarian lokasi yang terintegrasi dengan Google Map. Kemudian informasi yang ditawarkan, antara lain foto-foto indekos, jumlah ketersediaan kamar, fasilitas kamar, luas kamar, spesifikasi kamar mandi, fasilitas umum, fasilitas parkir, akses lingkungan, dan harga. Mamikos menerapkan model, yaitu dengan menggratiskan pemilik indekos untuk mengiklankan indekos mereka. Sebagaimana gambar 3.

Selain Mamikos juga terdapat Info Kost/Kontrakan yang merupakan sebuah akun Line yang berbasis akun resmi dengan menawarkan informasi indekos-indekos yang terdapat di sekitar Universitas Telkom dan juga menawarkan informasi seperti acaraacara menarik yang akan diselenggarakan oleh kampus. Saat menggunakan Info Kost/Kontrakan mahasiswa terlebih dahulu membuka Aplikasi Line kemudian terlebih dahulu menambahkan pertemanan dengan akun Info Kost/Kontrakan, lalu masuk ke beranda atau home Info Kost/Kontrakan, maka akan muncul informasi-informasi tentang indekos yang meliputi foto, fasilitas, harga, lokasi, dan nomor telepon pemilik indekos. Info Kost/Kontrakan menerapkan sistem promosi berbayar (paid promote) kepada pemilik indekos atau mahasiswa dengan membayarkan sejumlah uang atau pulsa sebagai biaya untuk mengiklankan kamar atau indekos mereka di Info Kost/Kontrakan. Hal ini berarti, Info Kost/Kontrakan hanya mempromosikan atau menampilkan informasi indekos yang menggunakan promo berbayar saja dan indekos yang tidak melakukan promo berbayar tidak tercantum dalam katalog informasi indekos yang disediakan oleh Info Kost/Kontrakan. Sebagaimana gambar

4.

\section{Gambar 3}

Fitur dan Informasi yang Ditawarkan oleh Mamikos

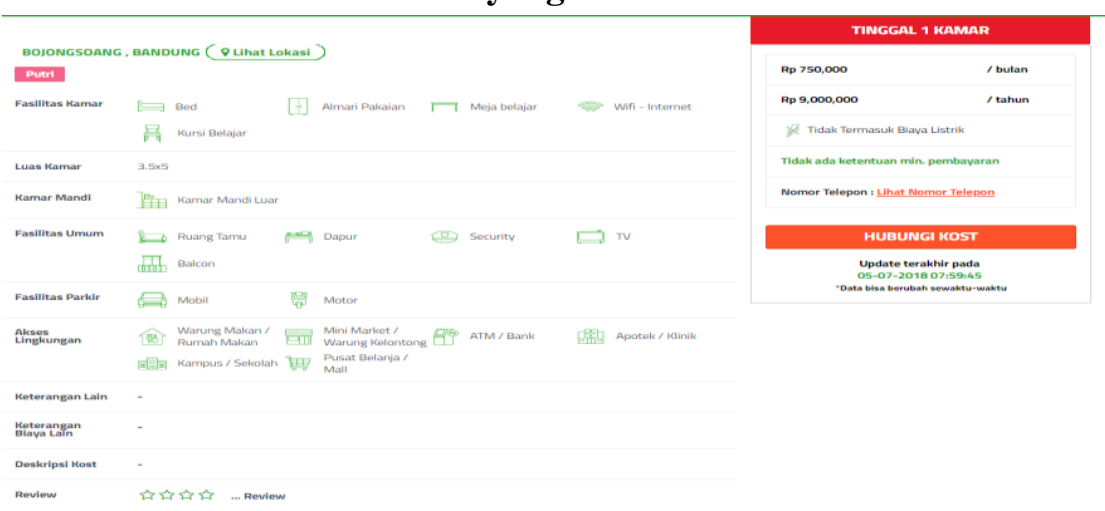

Sumber : https://mamikos.com/cari/universitas-telkom-bandung/all/bulanan/0-10000000 


\section{Gambar 4}

Info Kost/Kontrakan dalam Memiklankan Indekos
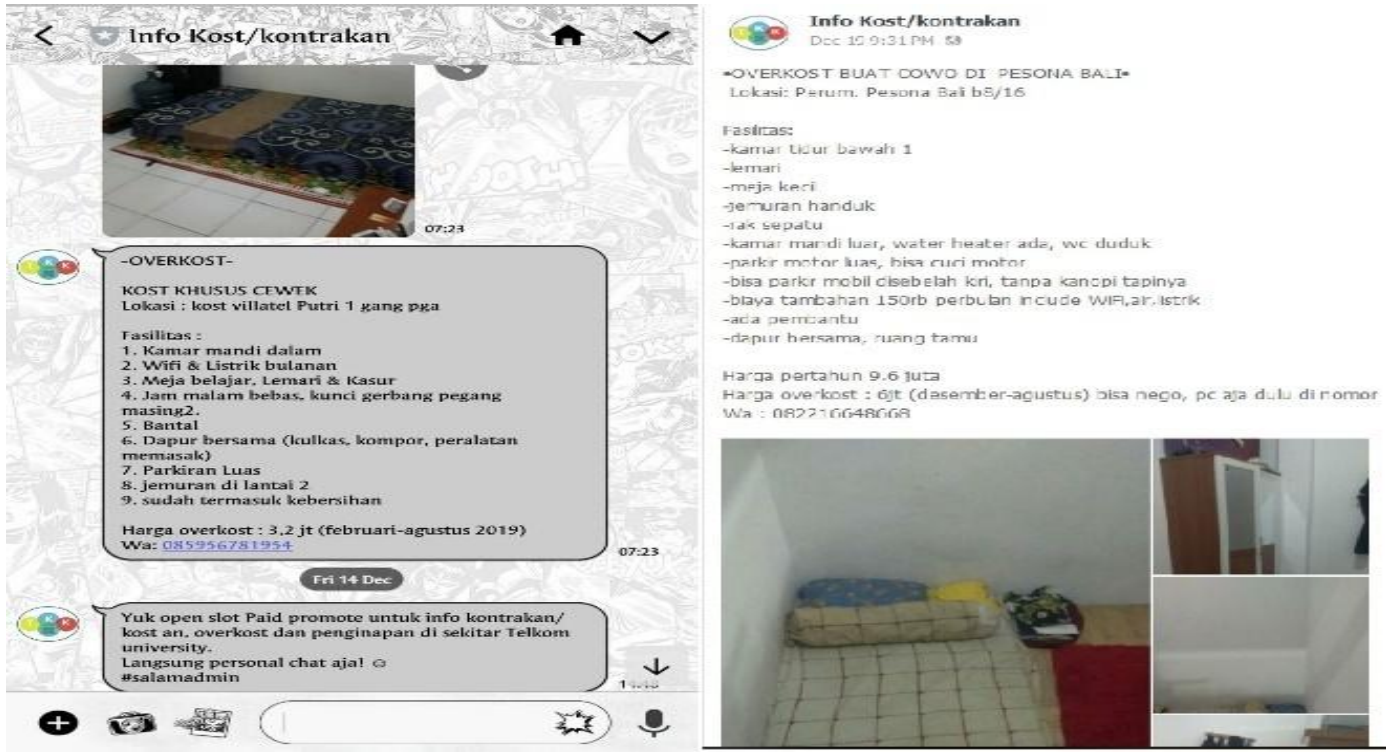

Sumber : https://mamikos.com/room/kost-bandung-kost-putri-murah-kost-permata-buahbatu-bojongsoang-bandung

Selain menggunakan observasi, peneliti juga menggunakan teknik wawancara. Hal ini dilakukan untuk mendapatkan informasi secara detail terhadap informan terkait customer jobs, costomer pains, dan customer gains. Informan pada penelitian ini adalah mahasiswa, khususnya adalah mahasiswa tingkat dua dan tiga. Alasan peneliti memilih informan tersebut karena mahasiswa tingkat dua dan tiga pernah mencari indekos dan dianggap masih mempunyai ingatan yang bagus berkaitan dengan pengalaman mencari indekos. Wawancara ini dilakukan berdasarkan pertanyaan pemicu yang sebelumnya telah dibuat oleh peneliti. Untuk mempermudah peneliti dalam mengolah data dari hasil wawancara, peneliti menggunakan alat rekam.
1. Hal yang paling banyak dilakukan mahasiswa dalam mencari indekos adalah mencari informasi tentang harga, lokasi, dan fasilitas indekos, survei indekos dengan menyusuri daerah-daerah sekitar kampus, dan bertanya tentang indekos yang sesuai kepada kakak tingkat atau teman sesama mahasiswa.

2. Dalam mencari informasi, paling banyak mahasiswa melakukan dengan survei indekos dengan menyusuri daerah-daerah sekitar kampus dan menggunakan media online seperti Mamikos dan Info Kost/Kontrakan.

3. Masalah yang banyak dialami dalam mencari indekos adalah waktu dan sulitnya mendapatkan informasi yang lengkap. 
4. Cara untuk mengatasi masalah yang telah di disebutkan di paragraf sebelumnya adalah adanya aplikasi yang menawarkan informasi indekos secara lengkap.

5. Kebutuhan yang paling penting bagi mahasiswa terkait dengan mencari indekos adalah informasi.

6. Kebutuhan mahasiswa dalam mencari indekos yang jika terpenuhi akan membuat mereka merasa puas adalah terpenuhinya informasi yang lengkap.

7. Hal yang dapat mengganggu atau kesulitan kebanyakan mahasiswa dalam mencari indekos adalah referensi indekos yang ditawarkan aplikasi indekos atau sejenisnya masih kurang.

8. Mahasiswa masih belum merasakan nilai yang ditawarkan oleh aplikasi indekos atau sejenisnya saat ini.

9. Mahasiswa merasa kesulitan dalam memindahkan barang-barang mereka ke indekos yang mereka huni saat ini.

10. Kebanyakan mahasiswa belum mengerti terkait harga dan layanan aplikasi indekos atau sejenisnya karena mereka dalam mendapatkan indekos bukan berasal dari aplikasi indekos dan harga yang ditawarkan jasa pengangkut barang tergolong mahal.
11. Informasi yang lengkap merupakan hal yang diharapkan mahasiswa dari adanya aplikasi indekos.

12. Fitur yang diharapkan mahasiswa pada aplikasi indekos adalah fitur forum obrolan, sistem booking, dan rating. Layanan yang diharapakan oleh para mahasiswa adalah layanan jasa angkut barang dan layanan mendampingi survei indekos.

13. Hal yang paling dicari oleh para mahasiswa terkait aplikasi indekos adalah yang menawarkan informasi secara lengkap dan memiliki desain yang bagus.

14. Banyak mahasiswa yang setuju dengan adanya layanan dalam membantu memindahkan barangbarang ke indekos mereka dengan harga yang terjangkau.

15. Hal yang membuat para mahasiswa senang atau lega adalah informasi yang ditawarkan lengkap dan adanya layanan jasa angkut barang.

\section{PEMBAHASAN}

Dalam membentuk customer jobs yang berkaitan dengan hal-hal apa yang dikerjakan oleh mahasiswa dalam mencari indekos, peneliti mengacu pada hasil observasi, yaitu mencari informasi, bertanya-tanya, melakukan kegiatan survei, dan menggunakan media online. Jadi, customer jobs yang dihasilkan adalah mencari informasi tentang harga, lokasi, dan fasilitas indekos, survei 
indekos dengan menyusuri daerahdaerah sekitar kampus, dan bertanyatanya tentang indekos yang sesuai kepada kakak tingkat atau teman-teman sesama mahasiswa.

Sehubungan dengan membentuk customer pains yang berkaitan dengan hal-hal apa yang dapat membuat mahasiswa merasa khawatir atau kesulitan dalam mencari indekos, peneliti mengacu pada hasil observasi, yaitu referensi indekos yang ditawarkan aplikasi indekos atau sejenisnya masih kurang, mereka kesulitan memindahkan barang-barang, harga yang ditawarkan oleh jasa angkut barang mahal. Peneliti juga mendapatkan informasi dari hasil wawancara dengan mahasiswa. Kesulitan mereka dalam mencari indekos, yaitu sulit mendapatkan informasi indekos yang lengkap antara lain informasi lokasi, harga untuk perbulan atau pertahun, dan fasilitas yang ditawarkan seperti meja, kursi, tempat parkir, internet, lalu referensi indekos yang ditawarkan oleh aplikasi indekos atau jenisnya masih kurang karena belum mencakup seluruh indekos disekitar lokasi kampus, kesulitan dalam memindahkan barang, harga jasa angkut yang tergolong mahal bagi mahasiswa karena range harga yang ditawarkan Rp. 100.000,00 sampai dengan Rp. 200.000,00 untuk sekali angkut dengan jarak kurang dari $3 \mathrm{~km}$ dari kampus dengan menggunakan mobil bak, akan tetapi mahasiswa mengharapkan range harga yang ditawarkan antara Rp. $50.000,00$ sampai dengan Rp. 100.000,00 untuk sekali angkut dengan jarak kurang dari $3 \mathrm{~km}$ dari kampus, serta kesulitan meluangkan waktu untuk mencari indekos karena jadwal kuliah dan kegiatan kampus yang padat. Berdasarkan hasil observasi dan wawancara yang dilakukan peneliti, maka customer pains yang relevan bagi segmen mahasiswa dalam mencari indekos adalah sulit mendapatkan infromasi yang lengkap, referensi yang ditawarkan oleh aplikasi indekos atau sejenisnya masih kurang, kesulitan memindahkan barang, harga jasa angkut barang yang mahal, dan kesulitan meluangkan waktu untuk mencari indekos.

Dalam membentuk customer gains yang berkaitan dengan hal-hal yang di inginkan atau diharap oleh segmen mahasiswa. Berdasarkan hasil wawancara yang telah dilakukan, peneliti mendapatkan hasil, antara lain informasi yang lengkap terkait harga, lokasi, dan fasilitas indekos, referensi indekos lebih banyak yang dapat mencakup seluruh indekos sekitar kampus, layanan jasa angkut barang yang harganya terjangkau dengan harga yang ditawarkan antara Rp. 50.000 sampai dengan Rp. 100.000 untuk sekali 
angkut dengan jarak kurang dari $3 \mathrm{~km}$ dari kampus, layanan mendampingi survei indekos, desain aplikasi bagus, dan fitur forum obrolan, rating, dan booking.

Berdasarkan hasil customer jobs, customer pains, dan customer gains yang telah ditentukan, maka hal selanjutnya adalah menuangkan poinpoin dari hasil tersebut ke dalam profil konsumen yang sesuai dengan desain proposisi nilai dari (Osterwalder dan Pigneur : 2014). Berikut merupakan profil konsumen dari segmen mahasiswa.

\section{Gambar 5}

\section{Profil Konsumen Segmen Mahasiswa}

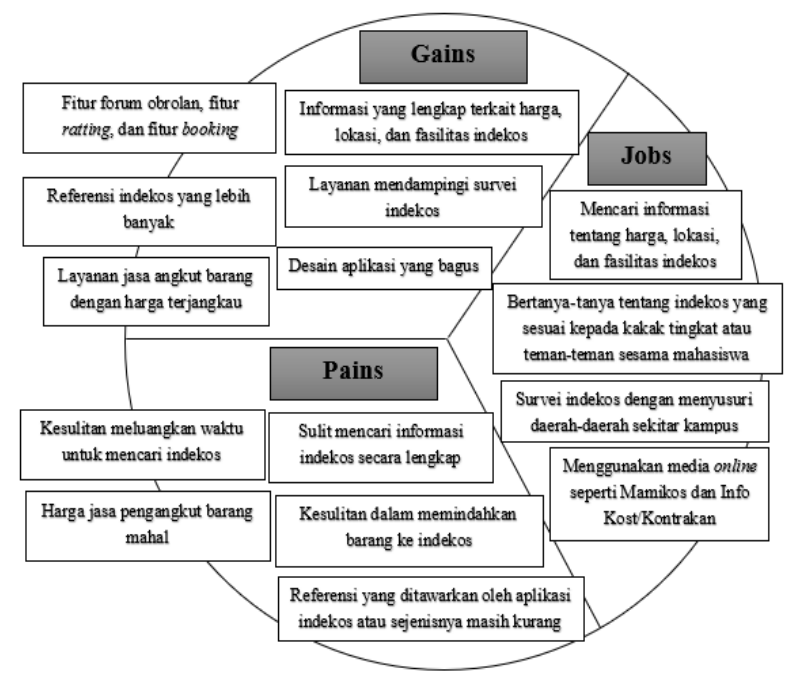

Sumber : Data diolah Peneliti

Berdasarkan profil konsumen yang telah dibentuk oleh peneliti di atas, peneliti akan membahas tentang proposisi nilai dari aplikasi indekos yang relevan dengan hasil dari profil konsumen. Menurut Osterwalder dan Pigneur dalam Business Model Generation (2010:22) Proposisi nilai diartikan sebagai kumpulan produk dan jasa yang memberikan nilai kepada segmen pelanggan yang spesifik. Proposisi nilai juga menjadi suatu alasan yang membuat pelanggan dapat beralih dari satu perusahaan ke perusahaan lain dan dapat memecahkan masalah atau kepuasan akan kebutuhan pelanggan. Proposisi nilai merupakan agregasi atau ikatan dari manfaat yang diberikan perusahaan kepada pelanggan. Proposisi nilai yang relevan dengan hasil dari profil konsumen, antara lain :

1. Menyediakan informasi indekos yang lengkap seperti informasi foto, harga, fasilitas, akses jalan atau akses dengan pusat perbelanjaan, dan lokasi yang diintegrasikan dengan Google Map kepada pelanggan. 
Hal tersebut dilakukan untuk mengatasi masalah mahasiswa, yaitu sulit mencari informasi indekos secara lengkap. Informasi indekos yang akan ditawarkan, antara lain fasilitas-fasilitas yang terdapat pada indekos, harga indekos baik pertahun atau perbulan, luas kamar, kamar mandi apakah di dalam atau di luar, akses lingkungan yang berkaitan dengan dekat dengan apotek atau pusat perbelanjaan serta yang lainnya, foto indekos yang banyak dan foto sesuai dengan realita aslinya, dan lokasi yang diitegrasikan dengan Google Map.

2. Menawarkan referensi indekos yang mencakup seluruh daerah sekitar kampus.

Hal ini dilakukan untuk mengatasi masalah mahasiswa, yaitu referensi indekos yang ditawarkan oleh aplikasi indekos atau sejenisnya masih kurang, sehingga perlu adanya proposisi nilai dalam menawarkan referensi indekos yang lebih banyak dan dapat mencakup seluruh daerah sekitar kampus.

3. Menawarkan layanan jasa pengangkut barang dengan harga yang terjangkau, yaitu dengan range harga Rp. 50.000,00 - Rp. 100.000,00 untuk sekali angkut dengan jarak kurang dari $3 \mathrm{~km}$ dari kampus menggunakan mobil bak.
Hal ini dilakukan untuk mengatasi masalah mahasiswa, yaitu merasa kesulitan dalam memindahkan barang-barangnya ke indekos yang akan mereka tempati dan mahasiswa merasakan harga yang ditawarkan oleh jasa pengangkut barang di sekitar kampus terlalu mahal, yaitu harga yang ditawarkan Rp. 100.000,00 sampai dengan Rp. 200.000,00 untuk sekali angkut dengan jarak kurang dari 3 $\mathrm{km}$ dari kampus dengan menggunakan mobil bak, akan tetapi mahasiswa mengharapkan range harga yang ditawarkan antara $\mathrm{Rp}$. 50.000,00 sampai dengan Rp. 100.000,00 untuk sekali angkut dengan jarak kurang dari $3 \mathrm{~km}$ dari kampus, sehingga perlu adanya layanan jasa pengangkut barang dengan harga yang terjangkau sehingga dapat membantu mahasiswa dalam memindahkan barang-barang mereka.

4. Menawarkan layanan pendampingi konsumen untuk survei ke indekos yang dituju.

Hal tersebut dilakukan untuk mengatasi masalah yang dialami mahasiswa ketika ingin melakukan kegiatan survei indekos karena mereka tidak mengetahui lokasi di mana indekos yang dituju berada dan mahasiswa yang tidak memiliki 


\section{FAKULTAS EKONOMI DAN BISNIS UNIVERSITAS WIRARAJA - SUMENEP}

kendaraan, sehingga untuk

memberikan kemudahan dan

mengatasi masalah mahsiswa, perlu adanya layanan untuk mendampingi mahasiswa melakukan survei indekos.

5. Menawarkan aplikasi dengan desain yang bagus dan menarik, seperti memiliki warna yang kontras, terdapat icon-icon yang, dan menggunakan kata-kata yang mudah dimengerti.

Hal tersebut perlu dilakukan karena mahasiswa menuntut adanya aplikasi yang memiliki desain yang bagus, seperti warna yang kontras, terdapat icon-icon yang, dan menggunakan kata-kata yang mudah dimengerti, sehingga mereka akan senang dan tidak merasa bosan menggunakan aplikasi karena desain yang ditawarkan menarik bagi mereka.

Menawarkan fitur-fitur
seperti forum obrolan yang
diperuntukkan sebagai wadah
komunikasi antara pemilik indekos
dengan konsumen, ratting yang
digunakan sebagai informasi tentang
penilaian sebuah indekos yang
disajikan dengan bintang, dan
booking yang digunakan untuk
pemesanan indekos sehingga indekos
yang telah dipesan tidak akan bisa
dipesan oleh orang lain.

Hal ini perlu dilakukan untuk memenuhi harapan dari mahasiswa, yaitu menginnginkan aplikasi yang memiliki fitur-fitur seperti forum obrolan, ratting, dan booking. Fitur forum obrolan merupakan wadah untuk menghubungkan mahasiswa dengan pemilik indekos untuk berdiskusi atau bertanya-tanya langsung, fitur ratting yaitu seperti penilaian berupa jumlah bintang yang diberikan oleh penghuni indekos terhadap indekos yang mereka tempati dengan memberikan jumlah bintang dari satu sampai lima bintang, dan fitur booking yang bertujuan untuk memberikan pemberitahuan kepada pengguna aplikasi ketika telah memesan indekos sehingga pengguna yang lain tidak dapat memesan indekos yang sama.

\section{KESIMPULAN}

Berdasarkan hasil penelitian serta analisis yang dilakukan oleh peneliti, dapat diambil kesimpulan yang digunakan untuk mengidentifikasi masalah yang dihadapi segmen mahasiswa, sehingga dapat dihasilkan profil konsumen yang sesuai dengan apa yang dirasakan oleh segmen mahasiswa. Kesimpulan yang didapat dari penelitian ini adalah harapan dan ekspektasi konsumen terhadap aplikasi indekos dengan ditujukkan pada profil 
konsumen yang dirancang oleh peneliti berdasarkan hasil wawancara dan observasi dengan segmen mahasiswa. Berikut merupakan tabel harapan dan ekspektasi segmen mahasiswa.

\begin{tabular}{cl} 
No & \multicolumn{1}{c}{$\begin{array}{c}\text { Kegiatan Segmen Mahasiswa } \\
\text { (Jobs) }\end{array}$} \\
1 & $\begin{array}{l}\text { Mencari informasi tentang harga, } \\
\text { lokasi, dan fasilitas indekos }\end{array}$ \\
2 & $\begin{array}{l}\text { Bertanya-tanya tentang indekos } \\
\text { yang sesuai kepada kakak tingkat } \\
\text { atau teman-teman sesama } \\
\text { mahasiswa }\end{array}$
\end{tabular}

3 Survei indekos dengan menyusuri daerah-daerah sekitar kampus

4 Menggunakan media online seperti Mamikos dan Info Kost/Kontrakan

$\begin{array}{cl}\text { No } & \begin{array}{l}\text { Keresahan Segmen Mahasiswa } \\ \text { (Pains) }\end{array} \\ 1 & \begin{array}{l}\text { Sulit mencari informasi indekos } \\ \text { secara lengkap }\end{array} \\ 2 & \begin{array}{l}\text { Kesulitan dalam memindahkan } \\ \text { barang ke indekos }\end{array} \\ 3 & \begin{array}{l}\text { Referensi yang ditawarkan oleh } \\ \text { aplikasi indekos atau sejenisnya } \\ \text { masih kurang }\end{array} \\ 4 & \begin{array}{l}\text { Kesulitan meluangkan waktu } \\ \text { untuk mencari indekos }\end{array} \\ 5 & \begin{array}{l}\text { Harga jasa pengangkut barang } \\ \text { mahal }\end{array}\end{array}$

\begin{tabular}{cl} 
No & \multicolumn{1}{c}{$\begin{array}{c}\text { Harapan Segmen Mahasiswa } \\
\text { (Gains) }\end{array}$} \\
1 & $\begin{array}{l}\text { Informasi yang lengkap terkait } \\
\text { harga, lokasi, dan fasilitas indekos }\end{array}$ \\
2 & $\begin{array}{l}\text { Layanan mendampingi survei } \\
\text { indekos }\end{array}$ \\
3 & $\begin{array}{l}\text { Fitur forum obrolan, fitur ratting, } \\
\text { dan fitur booking }\end{array}$ \\
$4 \quad \begin{array}{l}\text { Referensi indekos yang lebih } \\
\text { banyak }\end{array}$ \\
$5 \quad$ Desain aplikasi yang bagus \\
$6 \quad \begin{array}{l}\text { Layanan jasa angkut barang } \\
\text { dengan harga terjangkau }\end{array}$ \\
Sumber : Data Olahan Peneliti
\end{tabular}

\section{SARAN}

a. Bagi peneliti selanjutnya
1. Peneliti selanjutnya diharapkan mampu melaksanakan penelitian terhadap segmen lain.

2. Peneliti selanjutnya diharapkan mampu melaksanakan penelitian lebih luas dan dalam terhadap aplikasi indekos sehingga dapat meneliti keseluruhan blok pada Bisnis Model Kanvas.

b. Bagi Aplikasi Indekos

Bagi aplikasi indekos mengacu pada proposisi nilai yang sesuai untuk mengatasi masalah dan memenuhi harapan mahasiswa, maka peneliti memberikan saran sebagai berikut :

1. Menyediakan informasi indekos yang lengkap seperti informasi foto, harga, fasilitas, akses jalan atau akses dengan pusat perbelanjaan, dan lokasi yang diintegrasikan dengan Google Map kepada pelanggan.

2. Menawarkan referensi indekos yang mencakup seluruh daerah sekitar kampus.

3. Menawarkan layanan jasa pengangkut barang dengan harga yang terjangkau, yaitu dengan range harga $\mathrm{Rp}$. 50.000,00 - Rp. 100.000,00 untuk sekali angkut dengan jarak kurang dari $3 \mathrm{~km}$ dari kampus menggunakan mobil bak. 
4. Menawarkan layanan pendampingi konsumen untuk survei ke indekos yang dituju.

5. Menawarkan aplikasi dengan desain yang bagus dan menarik, seperti memiliki warna yang kontras, terdapat icon-icon yang, dan menggunakan kata-kata yang mudah dimengerti.

6. Menawarkan fitur-fitur seperti forum obrolan yang diperuntukkan sebagai wadah komunikasi antara pemilik indekos dengan konsumen, ratting yang digunakan sebagai informasi tentang penilaian sebuah indekos yang disajikan dengan bintang, dan booking yang digunakan untuk pemesanan indekos sehingga indekos yang telah dipesan tidak akan bisa dipesan oleh orang lain.

\section{DAFTAR PUSTAKA}

\section{Ahmadi, R. (2014). Metodologi Penelitian Kualitatif. Yogyakarta: Ar-ruza Media. \\ APJII. (2018 ). Hasil Survei Penetrasi Dan Perilaku Pengguna Internet Indonesia 2017. Jakarta: APJII (Asosiasi Penyelenggara Jasa Internet Indonesia)- https://doi.org/10.1016/j.seizure. 2011.01.014.}

Indrawati. (2015). Metode Penelitian Manajemen Dan Bisnis Konvergensi Teknologi
Komunikasi Dan Informasi. Bandung: PT Refika Aditama.

Kotler, P., \& Keller, K. L. (2009). Manajemen Pemasaran - Edisi 13. Jakarta: Erlangga.

Osterwalder, A., \& Pigneur, Y. (2010). Business Model Generation. Canada: Alex Media Komputindo.

Osterwalder, A., Pigneur, Y., Bernarda, G., \& Smith, A. (2014). Value Proposition Design. Canada: Wiley.

Sanjaya, M., \& Sisilia, K. (2018). Analisis Peluang Bisnis Ritel Konstruksi dengan Pendekatan Desain Proposisi Nilai. Jurnal Sekretaris dan Administrasi Bisnis, 4-19.

Sugiyono. (2013). Memahami Penelitian Kualitatif. Bandung: Alfabeta.

Wibawa, B. M., Baihaqi, I., Hakim, M. S., Kunaif, A., \& Anityasari, M. (2016). Business Model and Value Proposition Design for The Establishment of The Herbal Tourism Village in Surabaya. Kuala Lumpur: ResearchGate.

Yusuf, A. M. (2014). Metode Penelitian Kuantitatif, Kualitatif, \& Penelitian Gabungan - cetakan ke 3. Jakarta: Kencana.

Sumber online :

https://mamikos.com/cari/universitastelkom-bandung/all/bulanan/010000000 (Diakses 9 Desember 2018, Pukul 23.00)

https://mamikos.com/room/kostbandung-kost-putri-murah-kostpermata-buah-batubojongsoang-bandung (Diakses 10 Desember 2018, Pukul 01.30) 